\title{
Selected health behaviours in professionally active men and women
}

\begin{abstract}
Introduction. Women suffer from health problems more often and for a longer time, however it is generally men who die earlier.

Aim. The aim of this work is to compare the selected health behaviours of working men and women.

Material and methods. The research included 100 men and 100 women. The respondents were tested with the matched pair-selection method, taking into consideration four variables: place of residence, level of education, marital status, and age. The survey questionnaire was used.

Results. Men and women show similarities with respect to some health behaviours, showing significant differences (amount and kind of alcoholic beverages drunk, regularity of preventive checks) in relation to others.

Conclusions. Women's health behaviours are to be evaluated more positively than men's. Both men and women require intensive educational activities concerning the effects of anti-health behaviours, especially bad eating habits and irregularity of preventive checks.
\end{abstract}

Keywords: health behaviours, men, women.

DOI: $10.1515 /$ pjph-2017-0011

\section{INTRODUCTION}

In recent years, premature mortality of men has become a factor leading to research into the population's health condition as related to gender. Women's longer life was associated with their health condition, although the results of many Polish and world research show that their health condition is worse than that of man [1,2]. The question why women's average life expectancy is longer despite the fact that they have more health problems leads to searching for differences between both genders' health condition. Although, as research outcomes show, the subjective evaluation of the Poles' health condition and their care for health have been gradually improving, the results are still unsatisfactory. The socio-political, cultural, and, above all, social roles transformations influence also the changes in health behaviours of men and women $[1,3,4]$. Some research show that women care more for their health by having a good diet, by periodic and preventive testing and by following doctors' orders, however other research forewarn of more frequent risky (anti-health) behaviours, like heavy smoking or alcohol abuse. In this respect, women frantically follow men and that does not concern, as it has always been believed, only women from the margins of society, but affects also educated women holding responsible positions [5-7]. On the other hand, men have begun to watch their figures and appearance; therefore they are more frequently customers of gyms and beauty parlours. Therefore, the issue of comparison of men and women's health behaviours seems to be topical and interesting.

\section{AIM}

The aim of this work is to compare the selected health behaviours of working men and women.

\section{MATERIALS AND METHODS}

To answer the basic research questions, 100 men and 100 women between 20 and 64 years of age were examined. The demographic variables were controlled by matching persons using the pair-selection method, taking into consideration four variables: place of residence, level of education, marital status, and age. 33\% women and 33\% men were country residents, while $67 \%$ women and $67 \%$ men lived in a city. In the research group, $10 \%$ of both genders representatives declared vocational education, $9 \%$ general secondary education and $20 \%$ vocational secondary education. Bachelor's degree was declared by $18 \%$ of men and $18 \%$ of women, while master's degree was declared by $43 \%$ of both genders representatives. The research group comprised $36 \%$ single and $64 \%$ married men, as well as $32 \%$ single and $68 \%$ married women.

The 79-question survey questionnaire was used. In the article, only Part IV of the questionnaire was analysed, with the selected questions concerning health. 


\section{RESULTS}

In the first place, the examined persons were asked what is most harmful to their health. They could choose among the following: stimulants, non-compliance with healthy eating rules, not enough physical activity, stress, inappropriate medical care, lack of sleep, and other situations which, in their opinion, are significant. The results are shown in Figure 1.

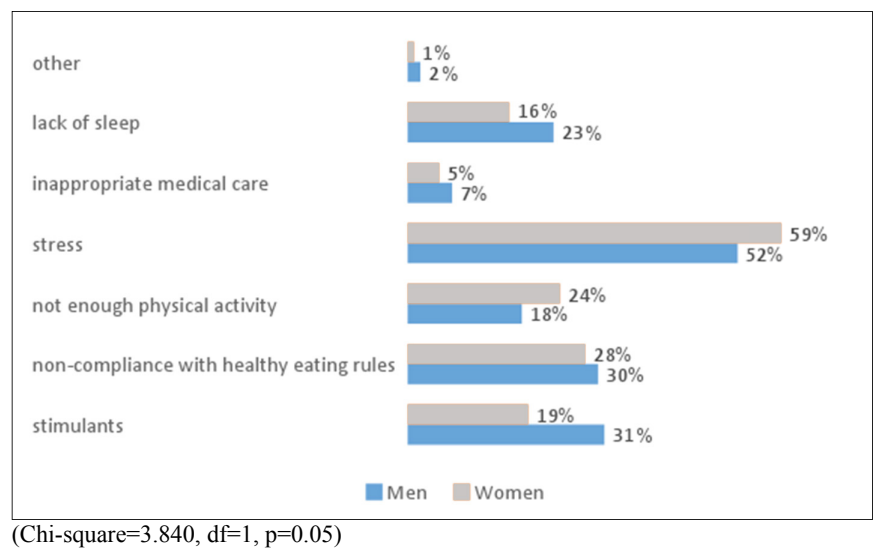

FIGURE 1. Factors most harmful to the respondents' health, in their opinion.

An analysis of the factors that are most harmful to health shows that in most aspects there is a high degree of similarity between answers given by men and women. According to the respondents, stress is the factor most harmful to their health. Almost $60 \%$ of women and $52 \%$ of men claim that they are constantly exposed to such a state. Another factor of similar significance for both genders is non-compliance with healthy eating rules $(28 \% \mathrm{~W}$ and $30 \% \mathrm{M})$. Not enough physical activity was mentioned by nearly a quarter of women $(24 \%)$ and one fifth of men $(18 \%)$. A similar number of respondents indicated the lack of sleep $(16 \% \mathrm{~W}$ and $23 \% \mathrm{M})$. Only with respect to stimulants (alcohol, coffee, cigarettes, red bull, and others) there was a statistically significant difference between men's and women's answers $(p=0.05)$. Nearly one third of men $(31 \%)$ answered that stimulants are a vital factor harmful to their health, while the same opinion was expressed by almost one fifth of women (19\%).

In order to specify what kind of stimulants differentiates the genders, the respondents were asked to determine the frequency of smoking cigarettes and drinking alcohol by them.

TABLE 1. Smoking cigarettes and drinking alcohol by men and women.

\begin{tabular}{|c|c|c|c|c|c|c|c|}
\hline \multicolumn{2}{|c|}{ Stimulants } & $\mathbf{N}$ & M & sd & $\mathbf{t}$ & df & $\mathbf{p}$ \\
\hline \multirow{2}{*}{$\begin{array}{l}\text { Smoking } \\
\text { cigarettes }\end{array}$} & M & 100 & 3.36 & 1.106 & \multirow{2}{*}{-1.658} & \multirow{2}{*}{189.239} & \multirow{2}{*}{0.099} \\
\hline & W & 100 & 3.60 & 0.891 & & & \\
\hline \multirow{2}{*}{$\begin{array}{l}\text { Drinking } \\
\text { alcohol }\end{array}$} & M & 100 & 3.26 & 0.860 & \multirow{2}{*}{-4.274} & \multirow{2}{*}{197.696} & \multirow{2}{*}{$0.001 * * *$} \\
\hline & W & 100 & 3.77 & 0.827 & & & \\
\hline
\end{tabular}

As presented in Table 1, smoking cigarettes in both groups (men and women) remains on a similar moderate level. The spread of results shows that $7 \%$ of women and $14 \%$ of men are heavy smokers. Also, a similar number of men and women smoke occasionally in various life and social situations $(11 \% \mathrm{~W}$ and $12 \% \mathrm{M}$ ). A similar tendency among the respondents of both genders is revealed in the results concerning their overcoming the habit, as $5 \%$ of women and $6 \%$ of men claim they have overcome their habit and are no longer smokers.
The results in Table 1 indicate statistically significant differences $(p=0.001)$ concerning drinking alcohol by men and women. A vast majority of men declare they drink alcohol often or sometimes $(63 \%)$, while a few of them drink it every day (4\%). Nearly $30 \%$ of men rarely drink alcohol, while $6 \%$ are teetotalers. In the case of women, approximately $80 \%$ declared rare or occasional alcohol drinking, while about $20 \%$ do not drink it at all. None of women declared drinking alcohol every day or often.

Taking into consideration the fact that alcohol is a factor that was definitely determined as harmful to health, the respondents were asked about kinds of alcoholic beverages they drink.

TABLE 2. The kind of alcohol drunk.

\begin{tabular}{lccccc}
\hline \hline Kind of alcohol & Men & Women & Chi-square & df & p \\
\hline vodka & $32.30 \%$ & $16.20 \%$ & $7.040 \mathrm{a}$ & 1 & $0.008^{* *}$ \\
\hline wine & $15.20 \%$ & $45.50 \%$ & $21.522 \mathrm{a}$ & 1 & $0.001^{* * *}$ \\
\hline beer & $64.6 \%$ & $35.4 \%$ & $16.990 \mathrm{a}$ & 1 & $0.001^{* * *}$ \\
\hline liqueurs & $2.0 \%$ & $11.1 \%$ & $6.669 \mathrm{a}$ & 1 & $0.010^{* *}$ \\
\hline do not drink at all & $6.1 \%$ & $16.2 \%$ & $5.114 \mathrm{a}$ & 1 & $0.024^{*}$ \\
\hline
\end{tabular}

An analysis of the collected material shows that the difference in drinking alcohol between men and women is not only quantitative (frequency of drinking), but also qualitative (kind of alcohol) (Table 2). Men definitely prefer beer $(p=0.001)$, which is connected with frequent or every day drinking, and vodka $(\mathrm{p}=0.008)$. Women, however, less frequently drink alcohol and they prefer wine, beer or flavoured liqueurs with low alcohol content. Among other kinds of alcohol, the respondents mentioned homemade products: flavoured vodkas, wine and tinctures.

Among the respondents highly aware of the necessity to take care of their own health, there is a great part (about $85 \%$ ) of both men and women who answered that they do not drink alcohol at all, and about $62 \%$ who claim they do not smoke heavily.

Pro-health behaviours include, among others: physical activities, healthy eating habits, preventive and periodic testing, maintaining a healthy lifestyle. Therefore, the respondents were asked about the above-mentioned lifestyle aspects.

TABLE 3. Pro-health behaviours of respodents.

\begin{tabular}{lccccccc}
\hline \multicolumn{1}{c}{ Questions } & \multicolumn{2}{c}{ Men } & Women & \multicolumn{2}{c}{$\begin{array}{c}\text { U-Man } \\
\text { Witney Test }\end{array}$} \\
\cline { 2 - 8 } & $\mathbf{M}$ & sd & M & sd & Z & p \\
\hline $\begin{array}{l}\text { Do you regularly do } \\
\text { any physical activities? }\end{array}$ & 3.10 & 0.931 & 3.12 & 0.891 & -0.147 & 0.441 \\
\hline $\begin{array}{l}\text { Is physical activity } \\
\text { connected with health, } \\
\text { in your opinion? }\end{array}$ & 4.40 & 0.586 & 4.36 & 0.560 & 0.494 & 0.311 \\
\hline $\begin{array}{l}\text { Do you think your diet is } \\
\text { healthy? }\end{array}$ & 2.92 & 1.11 & 2.98 & 0.88 & -0.63 & 0.950 \\
\hline $\begin{array}{l}\text { Do you regularly undergo } \\
\text { basic examinations? }\end{array}$ & 2.85 & 1.167 & 3.18 & 1.063 & -2.097 & $0.014^{* *}$ \\
\hline $\begin{array}{l}\text { Do you undergo preventive } \\
\text { checks? }\end{array}$ & 2.69 & 1.116 & 3.16 & 1.095 & -3.009 & $0.001^{* * *}$ \\
\hline $\begin{array}{l}\text { Do you think you lead } \\
\text { a healthy lifestyle? }\end{array}$ & 2.89 & 0.913 & 3.01 & 0.789 & -0.123 & 0.344 \\
\hline
\end{tabular}




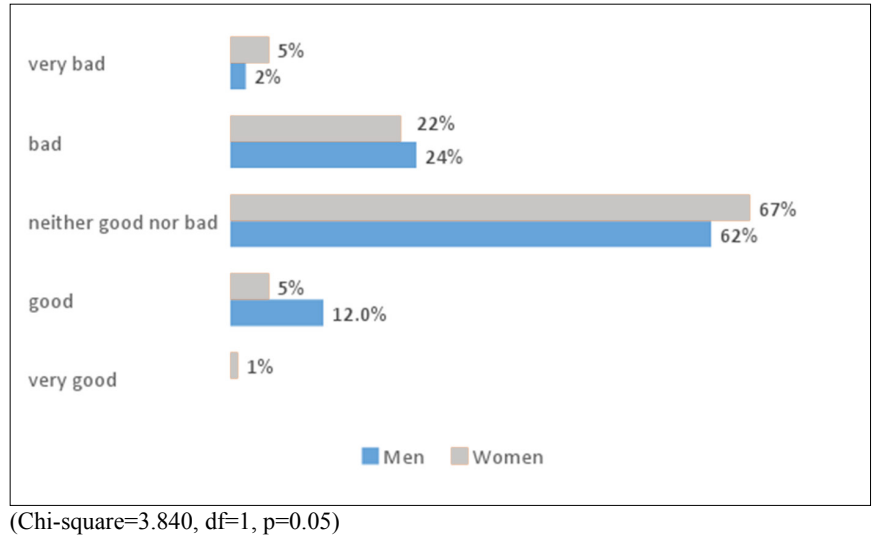

FIGURE 2. The evaluation of one's own health condition.

The respondents taking part in the research differ in a statistically significant way when it comes to regular undergoing examinations $(\mathrm{z}=-2.097, \mathrm{p}=0.014)$ and preventive checks $(\mathrm{z}=-3.009, \mathrm{p}=0.001)$, men achieving worse results. Although, no statistically significant differences were found in the points related to physical activity, healthy eating and their connection with health (Table 3). While answering the question about healthy diet, both men and women tended to choose the middle options: 'neither yes nor no'. Such a low indicator of extreme answers may suggest that the respondents are not sure whether they have appropriate eating habits.

In the following question, the respondents were asked to evaluate, as generally as possible, their current health condition. The results are shown in Figure 2.

The results show that both men and women perceive their health condition very similarly. The greatest number of people chooses the answer that their health condition is 'neither good nor bad' $(67 \% \mathrm{~W}$ and $62 \% \mathrm{M}) .22 \%$ of women and $24 \%$ of men describe their health condition as 'bad' or 'very bad', while $5 \%$ of women and $12 \%$ of men assessed it as 'good'. Out of 200 respondents taking part in the research, only one evaluated her health condition as 'very good'.

Looking for correlation between one's own health assessment and the frequency of smoking and drinking alcohol, with the help of Kendall rank correlation coefficient for pairs, it was found that there is an adverse relationship between the frequency of smoking and the general evaluation of one's own health condition (tau-b Kendall=-0.134, $\mathrm{p}=0.017$ ). This kind of relationship was not found between the evaluation of one's own health condition and excessive alcohol consumption (tau$\mathrm{b}$ Kendall $=-0.034, \mathrm{p}=0.586$ ). The respondents who frequently consume alcohol claim that such alcoholic beverages as beer or wine, despite being drunk regularly or often, do not harm their health as much as nicotine.

At the final stage of the research, the respondents were asked if they cared for their health condition. The results are shown in Figure 3.

Analysing the respondents' answers, it may be concluded that a vast majority of men and women show a high awareness related to taking care of their own health. The total $66 \%$ of men and $83 \%$ of women indicated that they take fairly good care of their health or that it is definitely important to them. However, a statistically significant difference $(p=0.01)$ between the opinions expressed by men and by women may be observed. Taking care of their health, women adopt temporary preventive measures $(75 \%)$, while only every second men tries to prevent health problems. In turn, systematic pro-health

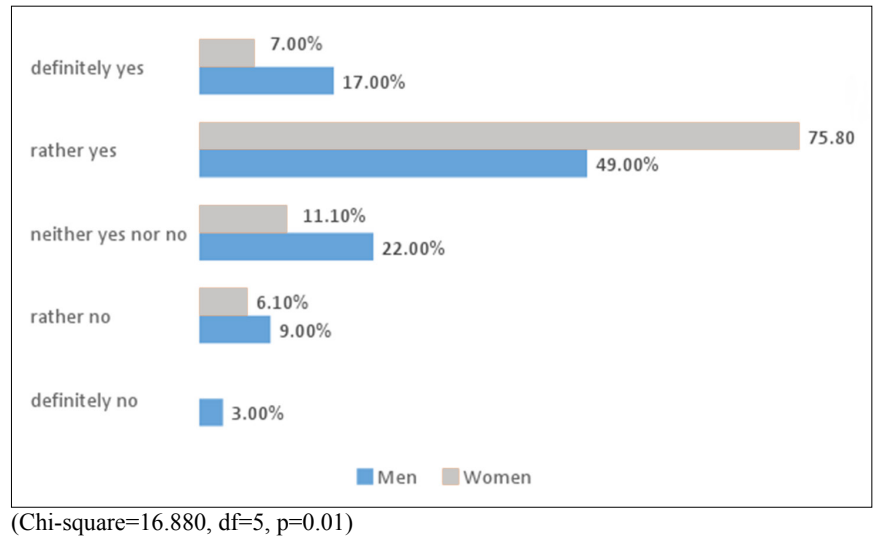

FIGURE 3. The assessment of the care for one's own health condition.

attitude concerns $17 \%$ of men and only $7 \%$ of women. About $6 \%$ of women and $9 \%$ of men take care of their health at a low level. However, no respondents marked the answer that he/she does not care for his/her health at all.

\section{DISCUSSION}

Health behaviours are a vital element of human life activity. Knowledge concerning this issue, as well as the ways of modifying those behaviours should contribute to improving the health of the society [4]. The results obtained show that men and women evaluate in a similar way the factors harmful to their health. In the first place, they mention stress, next the non-compliance with healthy eating rules and insufficient amount of sleep. The significant difference concerns only stimulants, and - as it was shown by in-depth analyses - only alcohol. When alcohol drinking is concerned, the differences are not only quantitative (frequency of drinking), but also qualitative (kind of alcohol). Men significantly more often prefer beer $(p=0.001)$ and vodka $(p=0.008)$, and it is connected with its frequent or daily consumption, while women less frequently drink alcoholic beverages, giving preference to wine, beer or liqueurs. The study results confirm the data provided by the literature [7]. However, no significant differences could be found in relation to smoking cigarettes, as $14 \%$ of men and $7 \%$ of women are heavy smokers, the smoking intensity remaining on a similar moderate level. Those results are much lower than the data presented in the current reports. In the research by Kaleta's et al. [8,9], 37.3\% of men and $28.2 \%$ of women smoked regularly. In the European Health Interview Survey (EHIS) of 2014, 29\% of adult men and $17 \%$ of women admitted to smoking every day. Many similar studies also showed that women smoke less frequently and that there is a general falling tendency in smoking [2,7], which is confirmed by the results of the presented study. Interestingly, however, heavy smokers are aware that their health condition is connected with the effects of smoking, while alcohol drinkers do not see a connection between their health condition and abusive drinking. Despite the fact that they drink alcohol regularly or often, they claim it does not harm their health as much as nicotine.

The basic dimensions of taking care of one's health include regular physical activities, such as recreational sports, healthy diet, and regular basic medical examinations, as well as participation in preventive screening programmes. The respondents taking part in the present study differed $(\mathrm{z}=-2.097$, $\mathrm{p}=0.01$ ) in regularity of undergoing basic and preventive medical examinations $(\mathrm{z}=-3.009, \mathrm{p}=0.001)$. Women definitely 
consider such measures as necessary for taking appropriate care of their health. A study testing health behaviours of senescent men [10] revealed that a higher rate of preventive behaviours is characteristic of men with higher education and those living in cities with a population of less than 100,000. Men and women do not differ in such pro-health behaviours as physical activity or healthy diet. The results concerning the latter issue show that the respondents are not sure whether their eating habits are appropriate. In the research concerning the assessment of health behaviours of men over 40 years of age, the correct eating habits achieved the lowest results [11]. Other researches also show that eating habits of the Polish population, in its different age groups, leave a lot to be desired [10, 12]. Therefore, there is a lot to do when it comes to health promotion [11].

The respondents do not differ also with respect to the perception of their health condition. It may be said that by choosing the middle answer (that their health condition is "neither good nor bad') they wanted, in a way, to remain safe. In the EHIS research quoted above, every fifth resident of Poland answered this way, with the worst assessment of their health given by the inhabitants of the Lubelskie and Lódzkie Voivodeships [2]. Although a vast majority of both women (83\%) and men $(66 \%)$ claim they take care of their health, women show a greater commitment and care in this respect, which confirms the results of the current research $[13,14]$.

\section{CONCLUSIONS}

1. Women's health behaviours are to be evaluated as more positive than men's.

2. Both men and women require intensive education concerning the effects of anti-health behaviours, especially bad eating habits.

3. In prophylactic actions directed to men, health consequences of abusive alcohol drinking and of neglecting preventive examinations need to be emphasized.

\section{REFERENCES}

1. Ostrowska A. Kobiety i mężczyźni. Jak styl i warunki życia różnicują zdrowie. Rocz Lubuski. 2006;32(2):113-29.

2. Zdrowie i zachowanie zdrowotne mieszkańców Polski w świetle Europejskiego Ankietowego Badania Zdrowia (EHIS) 2014 r. Warszawa: GUS; 2015. http://stat.gov.pl/files/gfx/portalinformacyjny/pl/defaultaktualnosci/5513/10/1/1/zdrowie_i_zachowania_zdrowotne_mieszkancow_ polski_w_swietle_badania_ehis_2014.pdf

3. Królikowska S. Nierówności ${ }^{-} \mathrm{w}$ stanie zdrowia między kobietami a mężczyznami w kontekście płci biologicznej oraz społeczno-kulturowej. Acta Univ Lodz. Folia Sociol. 2011;39:33-52.

4. Gruszczyńska M, Bąk-Sosnowska M, Plinta R. Zachowania zdrowotne jako istotny element aktywności życiowej człowieka. Stosunek Polaków do własnego zdrowia. Hygeia Public Health. 2015;50(4):558-565.

5. Chuchra M. Specyfika uzależnienia kobiet od alkoholu. Curr Probl Psychiatry. 2012;13(1):34-8.

6. Cylkowska-Nowak M, Plucińska M. Zdrowie kobiet i mężczyzn wybrane aspekty społeczne i medyczne. Rocz Pomor AM w Szczecinie. 2013; 59(1):103-13.

7. Korporowicz V. Różnice w zachowaniach zdrowotnych i kosztach leczenia kobiet i mężczyzn w Polsce. http://kolegia.sgh.waw.pl/pl/KES/czasopisma/kwartalnik/Documents/vkorporowicz15.pdf [20.08.2017]

8. Kaleta D, Makowiec-Dąbrowska T, Polańska K, Dziankowska-Zaborszczyk E, Drygas W. Palenie tytoniu i inne negatywne zachowania zdrowotne wśród osób czynnych zawodowo. Med Pr. 2009;60(1):7-14.

9. Kaleta D, Korytkowski P, Makowiec-Dąbrowska T. Palenie papierosów w populacji osób czynnych zawodowo. Med Pr. 2013;64(3):1-13.

10. Łepecka-Klusek C, Pałucka K, Bogusława Pilewska-Kozak A, PawłowskaMuc AK. Zachowania zdrowotne starzejących się mężczyzn. J Education, Health and Sport. 2015;5(5):496-509.

11. Arendt A, Laszczyńska M, Bażydło M, Kotwas A, Karakiewicz B. Ocena zachowań zdrowotnych mężczyzn po 40 roku życia. Probl Hig Epidemiol. 2014;95(3):659-66.

12. Suliga E. Zachowania zdrowotne związane z żywieniem osób dorosłych i starszych. Hygeia Public Health. 2010;45(1):44-8.

13. Zadworna-Cieślak M, Ogińska-Bulik N. Zachowania zdrowotne osób w wieku senioralnym - rola optymizmu. Psychogeriatria Pol. 2013;10(4):145-56.

14. Mandal E. Podmiotowe i interpersonalne konsekwencje stereotypów związanych z płcią. Katowice: WUŚ; 2000.

\section{Corresponding author}

Maria Chuchra

Department Public Health, Institute of Family and Social Work Studies, The John Paul II Catholic University of Lublin, Poland

Racławickie Av. 14, 20-950 Lublin

E-mail: mchuch@kul.lublin.pl 